\title{
A Conceptual Framework for Wealth Maximization: Literacy and Planning Embedded Model
}

\author{
Sheela Devi D Sundarasen ${ }^{1}$, Muhammad Sabbir Rahman ${ }^{2} \&$ Usha Rajagopalan $^{3}$ \\ ${ }^{1}$ Graduate School of Management, Multimedia University, Cyberjaya, Malaysia \\ ${ }^{2}$ Faculty of Language and Management, International Islamic university, Kuala Lumpur, Malaysia \\ 3 Taylor's Business School, Taylor's University, Sunway, Malaysia \\ Correspondence: Dr Sheela Devi D Sundarasen, Graduate School of Management (GSM), Multimedia University, \\ Persiaran Multimedia, 63100 Cyberjaya, Selangor Darul Ehsan, Malaysia. E-mail: sundarasen.sheela@gmail.com
}

Received: March 11, 2014

Accepted: March 25, 2014

Online Publication: May 27, 2014

doi: 10.5539/ibr.v7n6p186

URL: http://dx.doi.org/10.5539/ibr.v7n6p186

\begin{abstract}
The aim of this paper is to develop a conceptual framework for wealth maximization. The paper defines and presents conclusive issues pertaining to financial literacy, financial planning and wealth maximization and expect to paradigm a conceptual framework for a prospective investigation. The research attempts to ascertain the significance of demography, perception towards money and parental role on financial literacy, financial planning and wealth maximization. Further research is obligatory to validate empirically the framework through systematic investigations and to assess its viability as a wealth maximization model. It is envisioned that the creation of awareness and transfer of financial literacy and planning to individuals will liberate the government to delve on macro level issues for economic prosperity. The theme is original and positions itself as the beginning stream of financial literacy and planning research, ultimately crafting foundational contribution to wealth maximization.
\end{abstract}

Keywords: wealth maximization, financial literacy, financial planning

\section{Introduction}

Financial planning is a long-term process of wisely managing an individual's finances so as to achieve one's goals and financial freedom. A distinctive approach towards personal financial planning involves effective utilization of savings to gather wealth, followed by careful conservation of such wealth against value depreciation and losses and finally distribution of wealth at a later point of one's life (Malaysia Financial Planning Council, 2004). To ensure the above objectives are accomplished by the masses, it is pivotal to execute ingenious activities in creating the awareness on the importance of financial planning, irrespective of an individual's socioeconomic condition. This consciousness will intensify only if the targeted people have the elementary financial literacy.

The principles of inclusiveness and social justice in terms of wealth maximization of the general citizens are important factors to be implemented in the quest for realizing a high income and developed nation. For example, in the Malaysian context, among the sectors in focus under the Economic Transformation Program (ETP) is the financial services; EPP 7 discusses on 'Spurring the Growth of the Nascent Wealth Management Industry'. In a multi-racial country like Malaysia, a high rate of bankruptcy among young adults and the increased levels of household debt may act as a major deterrent in achieving the Vision 2020, which also envisions a financially balanced multi-racial society. In view of that, an all-encompassing research program by academicians is desirable for the policy-makers to identify the critical contributing factors towards wealth maximization. Thus, the objective of this concept paper is to derive a framework to identify the roots to wealth maximization, via integration of financial literacy and planning. It is obligatory to empirically validate the framework through systematic investigations and to assess its viability as a wealth maximization model, ultimately supporting citizens to strategize their wealth maximization roadmap. The creation of awareness and transfer of financial literacy and planning to respective individuals should liberate the government to undertake macro level issues for economic prosperity.

In the current fast-paced and evolving economy, individuals are expected to assume responsibility for their 
economic security in every stage of their life; right from the accumulation stage through the consolidation and retirement stages of their life. For these reasons, planning and saving as much and as soon as possible is highly recommended (Dennis \& Migliaccio, 1997; Glass \& Kilpatrick, 1998a; Salisbury, 1997). Similarly, in Western civilizations, the shift from collective to the distinct duty of financial preparation for retirement firmly authorizes research of this nature more challenging and treasured (Kemp \& Denton, 2003). Therefore, adequate financial literacy is important in assuring the right long-term financial planning and well-being.

En bloc, this conceptual paper will pull together information from secondary sources and advance an integrated conceptual framework to improve the financial literacy awareness and its transformation into increased financial planning in a holistic manner. The review will also attempt to identify the presence of demography, perception towards money and parental role as stimulus towards financial literacy, planning and wealth maximization. To date, academic studies have deliberated the causal factors of financial socialization, financial experiences and money attitudes on adolescents' financial knowledge, but minimal effort is undertaken to explore the links between financial literacy, financial planning and ultimately wealth maximization. In reality, an individual may be financially literate but may not have a proper financial plan in place for wealth maximization. Therefore, the main contribution expected from this conceptual paper is the exploitation of a framework which identifies the link between demography, perception towards money and parental role in the acquisition of financial literacy, financial planning and the desired wealth maximization.

The methodology employed in this research includes the review of extant literature pertaining to financial literacy and planning and its links towards wealth maximization. This will enable the conceptualization of an integrated model linking theories derived from past empirical and conceptual research in this area. The following paragraph will describe the development of the conceptual framework.

\section{Development of Conceptual Framework}

The ultimate goal for most individuals from a financial perspective is to obtain "financial freedom" at the earliest possible stage of their life. The degree of financial freedom may differ significantly from one person to another and is predominantly associated with their background, parental guidance and their perception towards money. To attain the aforementioned, it is essential that a certain degree of financial literacy is obtained by every individual, irrespective of age, race or gender.

Vitt, Anderson, Kent, Lyter, Siegenthaler and Ward (2000) define financial literacy as "a person's power to read, analyze, make out, and communicate personal finance issues". It denotes the attainment of knowledge and expertise essential to lever financial encounters and judgments in daily life. At the macro-level, financial literacy safeguards citizens of a country and ensures that they have adequate knowledge to transact with daily financial circumstances and transactions in the marketplace. Furthermore, financial literacy in terms of cognition and skills acquired early in life creates a foundation to the impending financial endeavors and security (Beverly \& Burkhalter, 2005; Martin \& Oliva, 2001). Financial literacy is also connected with financial experience and those with more financial experience is expected to unveil greater financial knowledge. Childhood experiences could be yet more important because financial occurrences within a family context enhance financial knowledge. The enhanced financial knowledge contributes towards a more structured and well thought through financial planning by individuals; this is imperative to an individual's wealth maximization. Wealth maximization is a long-term practice of intelligently managing one's moneys with the aim of obtaining intended enduring financial goals, while being able to overcome financial barricades at every level of life cycle. As such, this conceptual paper advocates that demography, parental role and an individual's perception towards money may act as key catalysts towards financial literacy, planning and eventual wealth maximization.

In that setting, literature has not fully explored (specifically, in a multi-racial context) on how the demographic factors impede individuals from initiating the proper financial provisions at the early phase of an individual's life cycle. However, research has inaugurated that education, career and remuneration are interrelated to financial planning and security in old age (Anderson, Bechhofer, McCrone, \& Stewart, 2000). A positive relationship is documented between household income and the outlook of financial planning (Schellenberg, 1994). Research on financial planning also recognizes that financial planning endeavors differ considerably amongst gender, race, income, education, occupation, age and marital status (Anderson et al., 2000; Glass \& Kilpatrick, 1998b; Gregoire, Kilty, \& Richardson, 2002) and the differences can have key bearings on an individual's retirement period. Men are more likely to be well equipped in financial planning for their later age as compared to women (Lee, 2003). Women have family obligations that deter them from working during certain periods of their life cycle. These factors cause a major impact on the financial planning aspects of women (Glass \& Kilpatrick, 1998b; Perkins, 1995; Richardson, 1990). Another demographic factor that warrants attention is an individual's 
age; most individuals are not too concerned about financial planning and wealth accumulation until they are much older (Anderson et al., 2000). In fact, studies by Statistics Canada (2001) and Turner, Bailey and Scott (1994) show that people from the higher age brackets are prospective financial planners. Reasons being, an individual's obligation on basic demand for money is of priority, such as purchasing of car, house and children's education. Plans for retirement take a backstage at this mid-age, whilst their concentration is more towards family and children (Turner et al., 1994). Obligation towards retirement planning also varies by marital status; marriage appears to possess monetary benefits in old years. Married men are more inclined towards effective financial planning (Gregoire et al., 2002) whilst, divorced or separated men or women seem to have inadequate security when reaching retirement. Nevertheless, McDonald (1997) found that widows have a greater likelihood to save when matched with divorced or separated women. Consequently, this conceptual paper proposes further investigation into the impact of diverse demographic characteristics on financial literacy, planning and wealth optimization.

In addition to demographic factors, a person's perception towards money is also perceived to play a predominant role in their quest to gain financial knowledge and the ensuing financial planning and wealth maximization. It is unanimously recognized that money is a dominant instrument and stimulus that profiles a person's status. It is customary that money is accepted by individuals as a symbol of distinction, whilst others reflect money as supremacy, omnipotence and hegemony, which attracts friendship and kinship. It is taken as a symbol of achievement and conquest, sovereignty and haven. Diverse perceptions about money have been found to be related to financial knowledge and conducts (Norvilitis, Merwin, Osberg, Roehling, Young, \& Kamas, 2006; Roberts \& Jones, 2001). Burgess (2005) found that an individual's outlook on money directly affects their life aspirations and confidence, implying that those attitudes are likely to act collectively with their personal behavior. As a result (depending on their attitude towards money), there is a possibility for individuals to pursue financial literacy, which will act as a platform towards wealth maximization. This was further endorsed by Edwards, Allen and Hayhoe (2007), who found that perception towards money were related to individuals' openness with parents on financial issues. These findings further suggested that particular money attitudes could function as a stimulus to financial knowledge seeking behavior. Similar conjectures (i.e., perception of money as an incentive for hard study or as an object in custody) were documented by Edwards et al. (2007). Therefore, this conceptual paper intends to further dwell into an individual's perception about money and its impact on financial literacy, planning and wealth optimization.

Along with an individual's perception towards money, it is proposed that the extent of financial literacy and planning largely molded by their relationship with their parents, relatives, friends, colleagues, teachers, etc. Consumer socialization theory emphasizes on the importance of social origins moulding consumer's knowledge and behavior (McLeod \& O'Keefe, 1972). Literature documents that parents take on a pivotal part in influencing adolescence on their money and saving attitudes (Clarke, Heaton, Israelsen, \& Eggett, 2005; Rettig, 1985). This is further supported by Lyons, Scherpf and Roberts (2006), who conjectures that parents play an essential role in aggregation of financial data by young adults. Parents who demonstrate constructive financial demeanors and more involved in unswerving coaching during youth were stalwartly looked upon by their off springs as financial role models. This further impulses them to act in tandem with parents' expectation on financial matters (Soroukou \& Weissbrod, 2005). In fact, it has been noticed that when parents are more convoluted and function as role models, young adults are more convinced of their financial undertakings (Shim, Xiao, Barber, \& Lyons, 2009). Study by Lyons et al. (2006) on high school and college students indicated that almost $77 \%$ of the students looked up to and depended on their parents to furnish them with the knowledge on financial literacy. Thus, the purpose of this conceptual paper is to specifically identify the parental role and to what extent it has an impact on the financial literacy and planning.

Grounded by the above literature, this conceptual paper seeks to realize these processes and we suggest the following conceptual framework: 


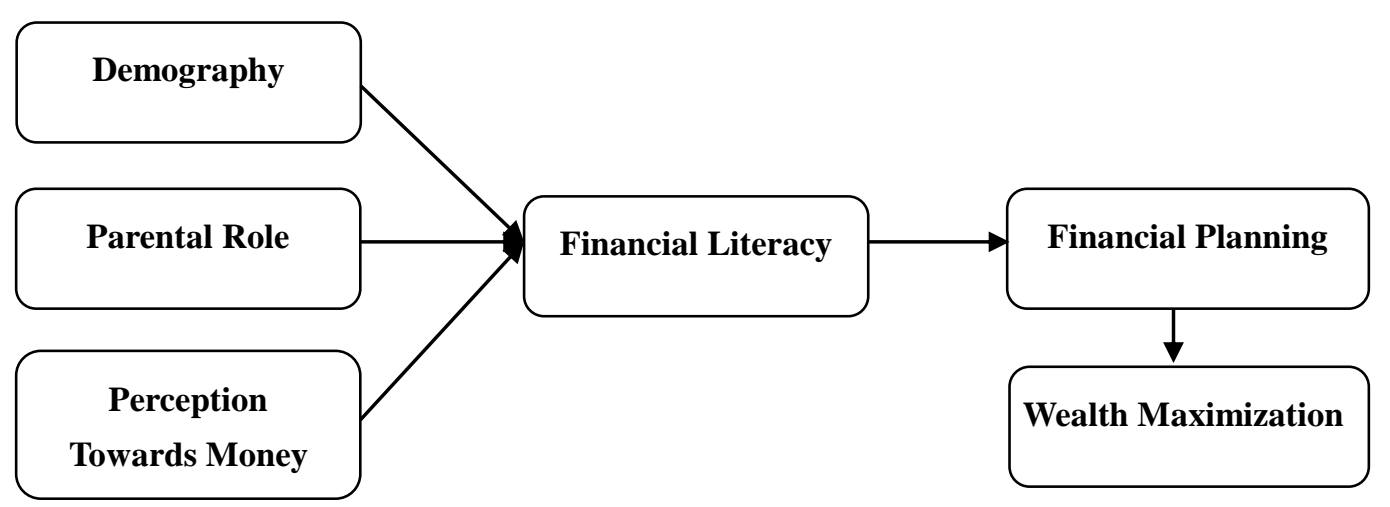

Figure 1. Conceptual framework for wealth maximization: literacy and planning embedded model

\section{Concluding Remarks}

The above conceptual model envisions that individuals and policy makers will have an exposure to a comprehensive self-sufficient platform on the antecedents of wealth maximization. This understanding would facilitate individuals, parents, educational institutions, employers and government with the accompanying items to contemplate and deliberate:

- Establishment on the importance of financial literacy and planning at every stage of an individual's life, in order to experience wealth maximization.

- Creation of awareness among parents on the importance of their role in ensuring transfer of adequate financial knowledge and experience to their offspring.

- Importance for employers in contracting seminars/training and coaching on financial literacy as part of Corporate Social Responsibility (CSR) and the support from Government via incentivizing these initiatives with tax exemptions.

- Involvement of NGOs in similar initiatives for people from all walks of life, by way of holding free sessions on financial literacy.

- Consideration by regulatory bodies and Education Ministries on the implementation of Financial Literacy Education as a compulsory module at all institutions of higher learning. Tax exemptions may be offered to individuals for attending classes on financial literacy from approved institutions.

In closing, if awareness on the importance of financial literacy and financial planning is instilled among all citizens, especially the young adults (who will eventually have families), it will benefit them enormously in their financial planning right at the onset of their career and minimize major financial mistakes which may require years to recuperate. Young adults who are equipped with adequate financial literacy will ensure proper financial planning is executed; which may include an appropriately diversified portfolio that can withstand the effects of financial crises. Proper financial planning can have favorable longer run effects in terms of financing their offspring's higher education (which can be seen as a major expenditure in many homes due to escalating cost of private teaching). This will effectively minimize an individual's dependence on government loans and issues ensuing it. Taking huge loans to finance education will suffer long-term effects as individuals will be embarking on their career with a financial baggage. Awareness of financial literacy and proper financial planning also takes on a pivotal part in retirement preparation. Here again, it will release dependence on government. Therefore, it is envisioned that every individual is given the exposure and privilege towards equipping themselves with adequate financial literacy, thus enabling them to achieve the degree of financial freedom they aspire in life, a.k.a wealth maximization.

\section{References}

Anderson, M., Li, L., Bechhofer, F., McCrone, D., \& Stewart, R. (2000). Sooner rather than later? Younger and middle-aged adults preparing for retirement. Ageing and Society, 20, 445-466. http://dx.doi.org/10.1017/S0144686X99007837

Beverly, S. G., \& Burkhalter, E. K. (2005). Improving the financial literacy and practices of youths. Children \& Schools, 27(2), 121-124. http://dx.doi.org/10.1093/cs/27.2.121 
Burgess, S. M. (2005). The importance and motivational content of money attitudes: South Africans with living standards similar to those in industrialized Western countries. South African Journal of Psychology, 35(1), 106-126. http://dx.doi.org/10.1177/008124630503500107

Carsky, M. L., Lytton, R. H., \& McLaughlin, G. W. (1984). Changes in consumer competency and attitudes: Do student characteristics make a difference? Proceedings of the American Council on Consumer Interests, USA, 30, 166-173.

Clarke, M. D., Heaton, M. B., Israelsen, C. L., \& Eggett, D. L. (2005). The acquisition of family financial roles and responsibilities. Family and Consumer Sciences Research Journal, 33, 321-340. http://dx.doi.org/10.1177/1077727X04274117

Dennis, H., \& Migliaccio, J. (1997). Redefining retirement: The baby boomer challenge. Generations Summer, $45-50$.

Edwards, R., Allen, M., \& Hayhoe, C. (2007). Financial attitudes and family communication about students' finances: The role of sex differences. Communication Reports, 20(2), 90-100. http://dx.doi.org/10.1080/08934210701643719

Glass, J. C., \& Kilpatrick, B. (1998b). Gender comparisons of baby boomers and financial preparation for retirement. Educational Gerontology, 24, 719-745. http://dx.doi.org/10.1080/0360127980240802

Gregoire, T. K., Kilty, K., \& Richardson, V. (2002). Gender and racial inequalities in retirement resources. Journal of Women and Aging, 14(3/4), 25-39. http://dx.doi.org/10.1300/J074v14n03_03

Kemp, C. L., \& Denton, M. (2003). The allocation of responsibility for later life: Canadian reflections on the roles of individuals, government, employers and families. Ageing and Society, 23(6), 737-760. http://dx.doi.org/10.1017/S0144686X03001363

Lee, Ronald, Andrew, M., \& Timothy, M. (2003). Life Cycle Saving and the Demographic Transition: The Case of Taiwan. In C. Chu \& R. Lee (Eds.), Population Change in East Asia, Transition, A Supplement to Volume 26 of Population and Development Review (pp. 194-222). New York: Population Council.

Lyons, A. C., Scherpf, E., \& Roberts, H. (2006). Financial education and communication between parents and children. Journal of Consumer Education, 23, 64-76.

Martin, A., \& Oliva, J. C. (2001). Teaching children about money: Applications of social learning and cognitive learning developmental theories. Journal of Family \& Consumer Sciences, 93(2), 26-29.

McDonald, D. (2002). TSC readers shine on financial literacy quiz. Retrieved from http://www.thestreet.com/funds/deardagen/9203371.html

McLeod, J. M., \& O'Keefe, G. J. Jr. (1972). The socialization prospective and communication behavior. In G. Kline, \& P. Tichenor (Eds.), Current perspectives in mass communication research (pp. 121-168). Beverly Hills, CA: Sage.

Norvilitis, J. M., Merwin, M. M., Osberg, T. M., Roehling, P. V., Young, P., \& Kamas, M. M. (2006). Personality factors, money attitudes, financial knowledge, and credit-card debt in college students. Journal of Applied Social Psychology, 36(6), 1395-1413. http://dx.doi.org/10.1111/j.0021-9029.2006.00065.x

Perkins, K. (1995). Social [in] security: Retirement planning for women. Journal of Women and Aging, 7, 37-53. http://dx.doi.org/10.1300/J074v07n01_04

Rettig, K. D. (1985). Consumer socialization in the family. Journal of Consumer Education, 3, 1-7.

Roberts, J. A., \& Jones, E. (2001). Money attitudes, credit card use, and compulsive buying among American college students. The Journal of Consumer Affairs, 35, 213-240. http://dx.doi.org/10.1111/j.1745-6606.2001.tb00111.x

Salisbury, D. L. (1997). Retirement planning and personal responsibility.

Schellenberg, G. (1994). The Road to Retirement. Ottawa. Centre for International Statistics, Canadian Council on Social Development.

Shim, S., Xiao, J. J., Barber, B. L., \& Lyons, A. C. (2009). Pathways to life success: A conceptual model of financial well-being for young adults. Journal of Applied Developmental Psychology, 30(6), 708-723. http://dx.doi.org/10.1016/j.appdev.2009.02.003

Sorokou, C. F., \& Weissbrod, C. S. (2005). Men and women's attachment and contact patterns with parents during the first year of college. Journal of Youth and Adolescence, 34(3), 221-228. 
http://dx.doi.org/10.1007/s10964-005-4304-5

Turner, M. J., Bailey, W. C., \& Scott, J. P. (1994). Factors influencing attitude toward retirement and retirement planning among midlife university employees. Journal of Applied Gerontology, 13, 143-156. http://dx.doi.org/10.1177/073346489401300203

Vitt, L. A., Anderson, C., Kent, J., Lyter, D. M., Siegenthaler, J. K., \& Ward, J. (2000). Personal finance and the rush to competence: Financial literacy education in the U.S. Washington, DC: Fannie Mae Foundation. Retrieved from http://www12.statcan.ca/english/census01/home/index.cfm

\section{Copyrights}

Copyright for this article is retained by the author(s), with first publication rights granted to the journal.

This is an open-access article distributed under the terms and conditions of the Creative Commons Attribution license (http://creativecommons.org/licenses/by/3.0/). 